\title{
Coronal dentinal tubules of non-erupted deciduous incisors
}

\section{Túbulos dentinários na dentina coronária de incisivos decíduos não-irrompidos}

Luciane Ribeiro de Rezende Sucasas da COSTA*

Ii-Sei WATANABE**

Marcia Consentino KRONKA***

COSTA, L. R. de R. S. da; WATANABE, I.; KRONKA, M. C. Coronal dentinal tubules of non-erupted deciduous incisors. Pesqui Odontol Bras, v. 16, n. 1, p. 12-17, jan./mar. 2002.

\begin{abstract}
The diameter and density of coronal dentinal tubules were assessed in non-erupted human deciduous incisors. Using liquid nitrogen, frozen samples were fractured in longitudinal and oblique directions and observed by means of a Jeol JSM-6100 scanning electron microscope. It was observed that the diameter of dentinal tubules ranged from 0.50 to 1.94 micrometers and increased significantly from the outer to the inner layers. However, comparing the incisal, middle and cervical thirds, no statistically significant differences were observed. The number of tubules per square millimeter varied from 3,281 to 32,313 and also increased from the external dentinal surface to the dentinal surface of the pulp chamber.
\end{abstract}

UNITERMS: Dentin; Tooth, deciduous; Pediatric dentistry.

\section{INTRODUCTION}

It is known that the diameter and number of dentinal tubules influence dental adhesion, since they are related to dentinal permeability. That is because the efficacy of most of the current adhesives depends upon the infiltration of the resin into the dentin ${ }^{13,17}$. Recently, it was verified that the amount of solid dentin is reduced in deciduous teeth due to differences in the number and diameter of dentinal tubules, in comparison with the dentin of permanent teeth ${ }^{20}$.

The aspect of the tubules depends not only on their location within the dentin, but also on the age of the tooth ${ }^{14}$. Many researchers have studied the tubular aspect and its relation with dentinal permeability in exfoliated teeth ${ }^{7,12,13,20,22}$, analyzing primary, secondary, and tertiary dentins. Hence, it is necessary to study the dentinal structure that has not yet been submitted to external stimuli (attrition, demineralization-remineralization challenges, technical procedures, etc.), in order to assess the characteristics of the tooth in its early moments in the oral cavity.

The objective of the present study was to determine the diameter and number of tubules in differ- ent areas of coronal dentin, using non-erupted deciduous incisors.

\section{MATERIAL AND METHODS}

Fifteen non-erupted human deciduous incisors with at least one third of their roots formed were utilized. They were extracted from five- to tenmonth-old children who had died 24 hours before oral autopsy, which was carried out at the Obit Verification Service, Hospital of Clinics, University of São Paulo, Brazil. The legal representative of this organ approved the utilization of the material.

The specimens were cleaned and fixed in modified Karnovsky's solution ${ }^{11}$, containing 2\% paraformaldehyde and $2.5 \%$ glutaraldehyde in $0.1 \mathrm{M}$ sodium phosphate buffer ( $\mathrm{pH} 7.4$ ) at $4^{\circ} \mathrm{C}$. After 24 hours, the samples were stored in $0.1 \mathrm{M}$ buffer solution ( $\mathrm{pH} 7.4$ ) at $4^{\circ} \mathrm{C}$, where they were kept until the moment of their fracture.

Ten teeth were frozen in liquid nitrogen and fractured in buccal-lingual direction with pliers. Five incisors were transversally fractured at the level of the pulp horn. Before the pliers were employed, a Carborundum disk fixed in a hand piece was used to confect a groove on the surrounding

*Adjunct Professor of Pediatric Dentistry, School of Dentistry, Federal University of Goiás.

**Full Professor; ***MS, Graduate Student - Department of Anatomy, Institute of Biomedical Sciences, University of São Paulo. 
COSTA, L. R. de R. S. da; WATANABE, I.; KRONKA, M. C. Coronal dentinal tubules of non-erupted deciduous incisors. Pesqui Odon-

tol Bras, v. 16, n. 1, p. 12-17, jan./mar. 2002.

enamel, in order to guide the fracture. The resultant specimens were dehydrated in increasing series of alcohol, cleaned in a Branson's ultrasonic apparatus for 10 minutes, and then dried in filter paper during 24 hours. The samples were mounted in metal stubs, covered with gold in a Balzers SCD-040 ions sputter, and examined in a Jeol JSM-6100 scanning electron microscope at $15 \mathrm{kV}$.

For measuring the dentinal tubules, pictures obtained from longitudinally fractured dentin, with a magnification of 4,500 times, were used. The following areas of comparison were established: a) incisal, middle, and cervical thirds; b) external (close to the amelodentinal junction), middle and internal (close to the pulp chamber wall) layers.

The diameter of the tubules was measured with the aid of a ruler, considering twenty points per picture. This procedure minimized errors caused by variations of diameter due to the random incidence of the fracture line. The average values obtained in each picture were used to compare different thirds and layers through the two-factor analysis of variance and Tukey's test. The significance level was established as 5\% (SAS System ${ }^{18}$ ).

Pictures of transversely fractured teeth were used to calculate tubular density (number of tubules per square millimeter), as well as the area filled by dentinal tubules, intratubular dentin and intertubular dentin. For those measurements, the formulas proposed by FORSSELL-AHLBERG et al. ${ }^{5}$ (1975) and PASHLEY ${ }^{16}$ (1989) were employed.

The authors counted tubule holes utilizing pictures of standardized magnification $(1,500 \mathrm{X})$, considering the external, middle and internal layers. Scores were compared to each other, using the two-factor analysis of variance and Tukey's test, with a significance level of $5 \%$ (SAS System ${ }^{18}$ ). The correlation between diameter and tubular density was evaluated by means of the coefficient of Pearson $^{21}$.

\section{RESULTS}

In longitudinal fractures, the average values of tubular diameter were obtained from 20 measurements registered in each picture. The measures varied from 0.50 to $1.94 \mu \mathrm{m}$, considering all thirds (incisal, middle and cervical) and layers (external, middle and internal).

The results revealed the following averages of tubular diameter in different layers: $0.65 \mu \mathrm{m}$ (ex- ternal), $1.13 \mu \mathrm{m}$ (middle) and $1.52 \mu \mathrm{m}$ (internal). Two-factor ANOVA revealed that these values were statistically different $(\mathrm{p}=0.0001)$.

In the external layer (Figure 1A), the averages found in each third were not statistically different: $0.62 \mu \mathrm{m}$ (cervical), $0.68 \mu \mathrm{m}$ (middle) and $0.66 \mu \mathrm{m}$ (incisal). In the middle layer (Figure 1B), the following values were verified: $1.09 \mu \mathrm{m}$ (cervical), $1.23 \mu \mathrm{m}$ (middle) and $1.05 \mu \mathrm{m}$ (incisal). At this level, there was significant difference between the incisal and middle thirds $(\mathrm{p}=0.0313)$. The averages registered for the internal layer (Figure 1C) did not present statistical difference: $1.57 \mu \mathrm{m}$ (cervical), $1.48 \mu \mathrm{m}$ (middle) and $1.5 \mu \mathrm{m}$ (incisal).

Comparing the measures obtained in the different thirds, there were no statistically significant differences $(p=0.664)$. The recorded average values were $1.10 \mu \mathrm{m}$ (cervical), $1.13 \mu \mathrm{m}$ (middle) and $1.07 \mu \mathrm{m}$ (incisal). The results were unable to demonstrate an interaction between layers and thirds $(\mathrm{p}=0.2244)$.

The average values of tubular density presented by the external, middle and internal layers were respectively 9,614, 17,018 and 23,114 tubules $/ \mathrm{mm}^{2}$, and the actual measures ranged from 3,281 to 32,313 tubules $/ \mathrm{mm}^{2}$. ANOVA and Tukey's test evidenced statistically significant differences between all layers $(p=0.001)$.

The authors also verified that there was an increase in the number and diameter of tubules from the outer to the inner layers of dentin. That was confirmed by the positive correlation revealed by the coefficient of Pearson (0.999993). The diameter and density of dentinal tubules in each layer allowed the researchers to calculate the area occupied by tubules, intratubular dentin and intertubular dentin (Table 1).

\section{DISCUSSION}

In the present study, the authors utilized solely non-erupted deciduous teeth, extracted in the beginning of root formation. In that state, the tooth presents with its original dentin, which has not yet suffered any of the multiple stimuli of the oral cavity. Thus, it was possible to compare non-erupted deciduous teeth with erupted deciduous and permanent teeth, studied in other researches.

Considering the diameter of dentinal tubules, the present results revealed values lower than those observed by HIRAYAMA et al. ${ }^{10}$ (1986), whose data varied from 2 to $15 \mu \mathrm{m}$, in the coronal dentin 
COSTA, L. R. de R. S. da; WATANABE, I.; KRONKA, M. C. Coronal dentinal tubules of non-erupted deciduous incisors. Pesqui Odontol Bras, v. 16, n. 1, p. 12-17, jan./mar. 2002.
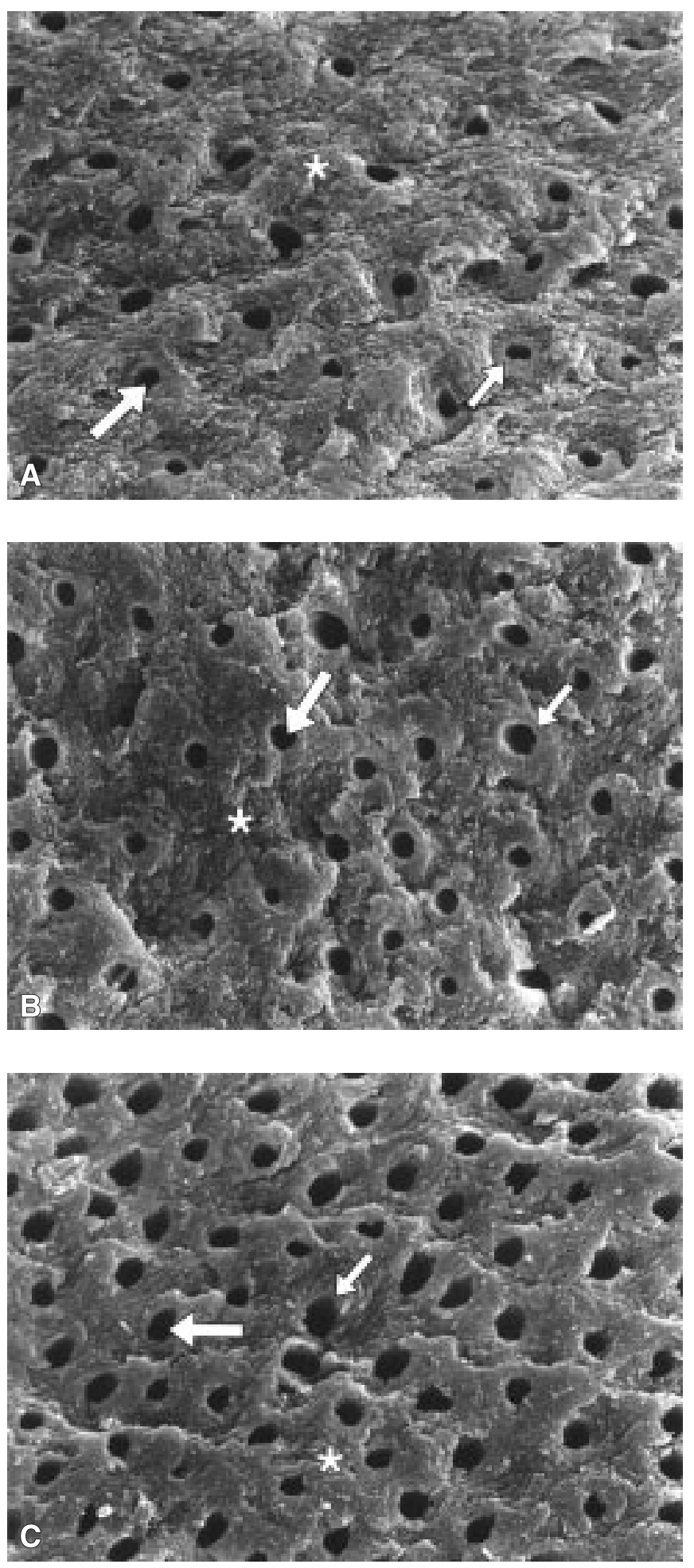

FIGURE 1 - SEM image of a transversally fractured deciduous incisor showing intertubular dentin (*), dentinal tubule holes (large arrows) and peritubular dentin (small arrows), in the external (A), middle (B) and internal (C) coronal regions $(3,200 \mathrm{X})$.
TABLE 1 - Dentinal area corresponding to tubules, intratubular and intertubular dentin, according to the distance from the pulp chamber.

\begin{tabular}{l|c|c|c}
\hline \hline \multirow{2}{*}{ Layers } & \multicolumn{3}{|c}{ Area (\%) } \\
\cline { 2 - 4 } & Tubules & $\begin{array}{c}\text { Intratubular } \\
\text { dentin }\end{array}$ & $\begin{array}{c}\text { Intertubular } \\
\text { dentin }\end{array}$ \\
\hline External & 0.32 & 0.96 & 98.72 \\
\hline Middle & 1.71 & 5.12 & 93.17 \\
\hline Internal & 4.19 & 12.58 & 83.23 \\
\hline \hline
\end{tabular}

of deciduous incisors. However, the observations are in agreement with those of WATANABE ${ }^{22}$ (1988), who reports values of tubular diameter ranging from 0.7 to $2.6 \mu \mathrm{m}$ in the pulp chamber wall of deciduous teeth, using scanning electron microscopy. HIRAYAMA et al. ${ }^{10}$ (1986), who employed electronic microscopy to study non-demineralized sections of deciduous incisors that were close to their exfoliating periods, could also measure giant tubules. On the other hand, the minimum value observed in the present research might result from the unaware inclusion of dentinal canalicula in the measurements of tubules, which has been pointed out by GARBEROGLIO; BRÄNNSTRÖM ${ }^{8}$ (1976).

The results regarding the inner coronal dentinal area, where the larger tubular diameters were registered, corroborated the data obtained with deciduous teeth ${ }^{3,7,12,13}$ and with permanent teeth ${ }^{4,7,8,12}$, and even with animals' teeth ${ }^{5}$. Those findings are related to the higher dentinal permeability of the internal layers of this tissue ${ }^{13,16}$. Only FOSSE et al. ${ }^{6}$ (1992) reported a discreet reduction in the diameters of dentinal tubules from the periphery of the dentin to its inner layers. It has been reported that various in vitro factors might affect tubular diameter, including demineralization of the structure, expansion of collagen, and the utilized fixative agent ${ }^{1}$.

In relation to the assessed dentinal thirds, it was not possible to establish a pattern of differentiation as to tubular diameter. However, GORACCI et al. ${ }^{9}$ (1993) verified an increase in tubular diameter from the occlusal $(1.8 \mu \mathrm{m})$ to the cervical $(3.5 \mu \mathrm{m})$ region. Those authors ${ }^{9}$ confirmed that the utilization of the coronal level for measuring tubular diameter and density, as reported in many papers, could also induce differences in the registered values. 
COSTA, L. R. de R. S. da; WATANABE, I.; KRONKA, M. C. Coronal dentinal tubules of non-erupted deciduous incisors. Pesqui Odon-

tol Bras, v. 16, n. 1, p. 12-17, jan./mar. 2002.

The results of the present paper are in agreement with those of several works that compared the number of tubules in different depths of dentin. Studying deciduous and permanent teeth, several papers report that tubular density increases from the outer to the inner dentin ${ }^{3,4,5,6,8,12,20}$.

Comparing the present values of density of dentinal tubules with those of other studies, an important variation of data was verified. The results were in agreement with those of COUVE; ONETTO $^{3}$ (1987), who found 10,000 tubules $/ \mathrm{mm}^{2}$ in mantle dentin (outer layer), and 20,000 tubules $/ \mathrm{mm}^{2}$ in circumpulpal dentin (middle layer), in germs of deciduous molars. These values are smaller than those presented in the literatu$\mathrm{re}^{2,4,5,6,8,9,12,13,19}$. COUVE; ONETTO ${ }^{3}$ (1987) also reported that while the secondary dentin of deciduous molars presented a greater number of tubules $\left(37,000 / \mathrm{mm}^{2}\right)$, the tertiary dentin presented a reduced density of tubules $\left(24,000\right.$ tubules $\left./ \mathrm{mm}^{2}\right)$, which is possibly due to the sclerosis of dentin. Similarly, CARRIGAN et al. ${ }^{2}$ (1984) observed decreased tubular density in old permanent teeth, when compared to recently erupted teeth.

According to the exposed results, the area corresponding to tubular dentin was smaller than that reported in studies carried out with permanent teeth ${ }^{4,16}$. Conversely, SFONDRINI et al. ${ }^{19}$ (1984) observed a larger tubular surface in deciduous teeth, when compared to permanent ones. The present authors stated that the area filled up with tubular and peritubular dentin in the internal layer was thirteen times larger than that found in the external layer, and five times larger than that found in the middle layer. The surface occupied by peritubular dentin was about three times larger than that occupied by tubules, in all layers. However, while in permanent teeth the area related to intertubular dentin half decreased from the external $(95.98 \%)$ to the internal layer $(51.23 \%)^{16}$, in deciduous teeth, this decrease corresponded to $15 \%$.

The results reported here reveal that deciduous teeth presented an area of intertubular dentin larger than that reported for permanent teeth. PASHLEY et al. ${ }^{17}$ (1993) affirmed that the penetration of resin into the intertubular dentin is the most important factor in dentinal adhesion. That property is named as intradentinal permeation. NÖR ${ }^{15}$ (1994) verified that the smear layer is easily removed from deciduous teeth, which could be justified by differences in the reactivity and chemical composition of that tissue, and also by the number of dentinal tubules. Based on those facts, the present researchers suggest that, in relation to the dentin of permanent teeth, the dentin of young deciduous teeth would be more favorable to resin retention since there is a small difference in the area of intertubular dentin, in the various evaluated depths. That aspect was more important than the observations regarding the intertubular surface in permanent teeth ${ }^{16}$. Additional researches should be carried out in order to test the numerous variables that influence dentinal adhesion in deciduous teeth.

PASHLEY $^{16}$ (1989) reported that the movement of dentinal fluid, which is related to dentinal permeability and pain, varies with the fourth potency of tubular diameter, which is more important than tubular length. According to PASHLEY ${ }^{16}$ (1989), the tubular functional diameter corresponds to the tenth part of the anatomical diameter due to the presence of intratubular deposits. So, if dentinal tubules presented smaller diameter and density in deciduous teeth, the dentin of deciduous teeth should be less permeable than that of permanent teeth, which has been proven by KOUTSI et al. ${ }^{13}$ (1994). KOUTSI et al. ${ }^{13}$ (1994) suggested that the permeability of recently erupted teeth was higher than that of exfoliated teeth, but this statement was not supported by the present results. Data revealed that, in the same tooth, permeability increases from the external to the internal dentinal regions because the diameter and density of tubules are greater in the internal layer.

Another clinical aspect related to dentinal tubules in deciduous teeth is the development of tooth decay. KOUTSI et al. ${ }^{13}$ (1994) postulated that the fast progress of carious lesions in deciduous teeth is not due to increased dentinal permeability. Our study may sustain that theory since the exposed values of tubular diameter and density were smaller than those related to permanent teeth. Considering that characteristic, there could be other factors associated with the progress of caries, such as the extent of deciduous dentin. Further works should be carried out in order to review the concepts on the evolution of carious lesions in deciduous teeth. 
COSTA, L. R. de R. S. da; WATANABE, I.; KRONKA, M. C. Coronal dentinal tubules of non-erupted deciduous incisors. Pesqui Odontol Bras, v. 16, n. 1, p. 12-17, jan./mar. 2002.

\section{CONCLUSIONS}

Based on the results of the present study, which evaluated the coronal dentin of non-erupted human deciduous incisors, the authors concluded that:

1. The diameter of dentinal tubules ranged from 0.50 to $1.94 \mu \mathrm{m}$, increasing from the dentin close to the amelodentinal junction to that close to the pulp chamber.

2. The average values of diameter were $0.65 \mu \mathrm{m}$ in the external layer, $1.13 \mu \mathrm{m}$ in the middle layer, and $1.52 \mu \mathrm{m}$ in the internal layer of dentin $(\mathrm{p}=0.0001)$.

3. There were no statistically significant differences regarding tubular diameter $(p>0.05)$ in the incisal, middle, and cervical thirds.

4. The average number of dentinal tubules, per square millimeter, increased $(p=0.0001)$ from the outer layer $(9,613)$ to the middle $(17,018)$ and inner layers of dentin $(23,114)$. The values ranged from 3,281 to 32,313 tubules $/ \mathrm{mm}^{2}$.

\footnotetext{
COSTA, L. R. de R. S. da; WATANABE, I.; KRONKA, M. C. Túbulos dentinários na dentina coronária de incisivos decíduos não-irrompidos. Pesqui Odontol Bras, v. 16, n. 1, p. 12-17, jan./mar. 2002.
}

\begin{abstract}
Foram estudadas as medidas do diâmetro e quantidade dos túbulos dentinários presentes na coroa de incisivos decíduos humanos não-irrompidos. Ao microscópio eletrônico de varredura, avaliaram-se tais parâmetros em amostras fraturadas longitudinal e transversalmente em nitrogênio líquido. O diâmetro dos túbulos dentinários variou de 0,50 a 1,94 micrômetros, sendo crescente da região externa para a interna, e as diferenças foram estatisticamente significantes. Entretanto, não houve diferença estatística quando comparados os terços incisal, médio e cervical. A quantidade de túbulos por milímetro quadrado variou de 3.281 a 32.313, e o número aumentou da região dentinária externa para a mais interna.
\end{abstract}

UNITERMOS: Dentina; Dente decíduo; Odontopediatria.

\section{BIBLIOGRAPHIC REFERENCES}

1. ARENDS, J.; STOKROOS, I.; JONGEBLOED, W. G.; RUBEN, J. The diameter of dentinal tubules in human coronal dentin after demineralization and air drying - a combined light microscopy and SEM study. Caries Res, v. 29, n. 2, p. 119-121, Mar./Apr. 1995.

2. CARRIGAN, P. J.; MORSE, D. R.; FURST, M. L.; SINAI, I. H. A scanning electron microscopic evaluation of human dentinal tubules according to age and location. $\mathbf{J}$ Endod, v. 10, n. 8, p. 359-363, Aug. 1984.

3. COUVE, E.; ONETTO, J. E. Aspectos dinámicos de la dentinogénesis en dientes temporales humanos. Rev Chil Odontoestomatol, v. 1, n. 2, p. 92-98, Dec. 1987.

4. DOURDA, A. O.; MOULE, A. J.; YOUNG, W. G. A morphometric analysis of the cross-sectional area of dentin occupied by dentinal tubules in human third molar teeth. Int Endod J, v. 27, n. 4, p. 184-189, July 1994.

5. FORSSELL-AHLBERG, K.; BRÄNNSTRÖM, M.; EDWALL, L. The diameter and number of dentinal tubules in rat, cat, dog and monkey - a comparative scanning electron microscopic study. Acta Odontol Scand, v. 33, n. 5, p. 243-250, 1975.

6. FOSSE, G.; SAELE, P. K.; EIDE, R. Numerical density and distributional pattern of dentinal tubules. Acta Odontol Scand, v. 50, n. 4, p. 201-210, Aug. 1992.

7. FROMME, V. H. G.; RIEDEL, H. Messungen über die Weite der Dentinkanälchen an nichtentmineralisierten blei- benden Zähnen und Milchzähnen. Dtsch Zahnarztl Z, v. 25, n. 3, p. 401-405, März 1970.

8. GARBEROGLIO, R.; BRÄNNSTRÖM, M. Scanning electron microscopic investigation of human dentinal tubules. Arch Oral Biol, v. 21, n. 6, p. 355-362, 1976.

9. GORACCI, G.; MORI, G.; CASA DE'MARTINIS, L.; BAZZUCCHI, M. Analisi ultrastrutturale della dentina peritubulare e del lume tubulare di denti sani. Minerva Stomatol, v. 42, n. 5, p. 205-216, mag. 1993.

10. HIRAYAMA, A.; YAMADA, M.; MIAKE, K. An electron microscopic study on dentinal tubules of human deciduous teeth. J Tokyo Dent Coll Soc, v. 86, n. 6, p. 1021-1031, June 1986.

11. KARNOVSKY, M. J. A formaldehyde-glutaraldehyde fixative of high osmolality for use in electron microscopy. In: ANNUAL MEETING OF THE AMERICAN SOCIETY FOR CELL BIOLOGY, 5. Philadelphia, Nov. 10-12, 1965. Abstracts of papers. New York. J Cell Biol, v. 27, 1965. p. 137A-138A. [Abstract n. 270].

12. KETTERL, V. W. Morphologische Untersuchungen über das Dentin der Milchzähne. Dtsch Zahnärtz Z, v. 20, n. 6, p. 652-657, Juni 1965.

13. KOUTSI, V.; NOONAN, R. G.; HORNER, J. A. et al. The effect of dentin depth on the permeability and ultrastructure of primary molars. Pediatr Dent, v. 16, n. 1, p. 29-35, Jan./Feb. 1994.

14. MJÖR, I. A. Dentin and pulp. In: MJÖR, I. A.; FEJERSKOV, O. Human embriology and histology. Copenhagen : Munksgaard, 1986. p. 90-130.

15. NÖR, J. E. Dentin bonding: SEM comparison of dentin 
COSTA, L. R. de R. S. da; WATANABE, I.; KRONKA, M. C. Coronal dentinal tubules of non-erupted deciduous incisors. Pesqui Odon-

tol Bras, v. 16, n. 1, p. 12-17, jan./mar. 2002.

surface and resin-dentin interface in primary and permanent teeth. 1994. 180 p. Thesis (Master of Science) - School of Dentistry, University of Michigan.

16. PASHLEY, D. H. Dentin: a dynamic substrate - a review. Scanning Microsc, v. 3, n. 1, p. 161-176, Mar. 1989.

17. PASHLEY, D. H.; CIUCCHI, B.; SANO, H.; HORNER, J. A. Permeability of dentin to adhesive agents. Quintessence Int, v. 24, n. 9, p. 618-631, Sept. 1993.

18. SAS ${ }^{\circledR}$ Institute Inc. SAS ${ }^{\circledR}$ proprietary software release 6.09. Cary, 1985.

19. SFONDRINI, G.; SCHIAVI, A.; PIACENTINI, C.; RYSKY, C. Studio al microscopio elettronico a scansione dei tubuli dentinali in denti umani decidui. Riv Ital Stomatol, v. 53, n. 5, p. 347-353, mag. 1984.

20. SUMIKAWA, D. A.; MARSHALL, G. W.; MARSHALL, S. J. Microstructure of primary tooth dentin. Pediatr Dent, v. 21 , n. 7, p. 439-444, Nov./Dec. 1999

21. VIEIRA, S. Noções sobre correlação. In: Introdução à bioestatistica. 2. ed. Rio de Janeiro : Campus, 1991. p. 51-61.

22. WATANABE, I. Scanning electron microscopy of the pulp chamber walls in human deciduous upper incisor. Rev Odontol Univ São Paulo, v. 2, n. 1, p. 51-55, jan./mar. 1988. 